(2)

\title{
Endocrine effects of tobacco smoke exposure during lactation in weaned and adult male offspring
}

\author{
A P Santos-Silva', E Oliveira', C R Pinheiro', A C Santana ${ }^{2}$, C C Nascimento-Saba ${ }^{2}$, \\ Y Abreu-Villaça ${ }^{3}$, E G Moura' and P C Lisboa ${ }^{1}$ \\ ${ }^{1}$ Laboratory of Endocrine Physiology, ${ }^{2}$ Laboratory of Morphofunctional Analysis and ${ }^{3}$ Laboratory of \\ Neurophysiology, Department of Physiological Sciences, Roberto Alcantara Gomes Biology Institute, State \\ University of Rio de Janeiro, Avenida 28 de setembro, 87, Rio de Janeiro, RJ 20551-030, Brazil
}

Correspondence should be addressed to P C Lisboa Email pclisboa@uerj.br

\begin{abstract}
Children from pregnant smokers show more susceptibility to develop obesity in adult life. Previously, we failed to demonstrate a program for obesity in rat offspring only when the mothers were exposed to tobacco smoke during lactation. Here, we studied the short- and long-term effects of smoke exposure (SE) to both dams and their pups during lactation on endocrine and metabolic parameters. For this, we designed an experimental model where nursing rats and their pups were divided into two groups: SE group, exposed to smoke in a cigarette smoking machine (four times/day, from the third to the 21 st day of lactation), and group, exposed to filtered air. Pups were killed at 21 and 180 days. At weaning, SE pups showed lower body weight $(7 \%)$, length $(5 \%)$, retroperitoneal fat mass $(59 \%)$, visceral adipocyte area (60\%), and higher subcutaneous adipocyte area (95\%) with hypoinsulinemia (-29\%), hyperthyroxinemia (59\%), hypercorticosteronemia $(60 \%)$, and higher adrenal catecholamine content $(+58 \%)$. In adulthood, SE offspring showed higher food intake $(+10 \%)$, body total fat mass $(+50 \%)$, visceral fat mass (retroperitoneal: $55 \%$; mesenteric: $67 \%$; and epididymal: $55 \%$ ), and lower subcutaneous adipocyte area (24\%) with higher serum glucose $(11 \%)$, leptin $(85 \%)$, adiponectin (1.4-fold increase), total triiodothyronine $(71 \%)$, free thyroxine $(57 \%)$, TSH $(36 \%)$, triglycerides $(65 \%)$, VLDL cholesterol $(+66 \%)$, and HDL cholesterol (91\%) levels and lower corticosteronemia (41\%) and adrenal catecholamine content (57\%). Our present findings suggest that tobacco SE to both dams and their pups during lactation causes malnutrition in early life that programs for obesity and hormonal and metabolic disturbances in adulthood, only if the pups are submitted to the same smoke environment as the mother.
\end{abstract}
Key Words
- lactation
- smoking
- hormones
- lipids
- adipose tissue
- programming

Journal of Endocrinology

(2013) 218, 13-24

\section{Introduction}

Approximately $20 \%$ of women in the world are smokers (WHO 2010). This information awakens the interest about the effects of smoking on two important phases of woman's life: gestation and lactation. Some studies have associated smoking during these periods with fetal growth restriction, preterm delivery, ectopic pregnancy, spontaneous abortion, and obesity development and its comorbidities, such as hypertension in childhood or 
adult life (von Kries et al. 2002, Wideroe et al. 2003, Goldani et al. 2007, Einarson \& Riordan 2009, Braun et al. 2010, Durmus et al. 2011).

Events or stimuli that occurred in the perinatal period (gestation or lactation) can permanently alter epigenetic markers such as histone acetylation/deacetylation or DNA methylation pattern, which can increase the risk of disease development in adult life. This association between early events (such as maternal smoking) and late consequences (such as obesity) exemplifies a phenomenon known as metabolic programming (de Moura et al. 2008, Lisboa et al. 2012). Recently, some studies have shown that tobacco exposure in utero is associated with changes in gene methylation profile (Suter et al. 2010, 2011), and the same event was observed in nicotine exposure (the main cigarette component)- changes the gene methylation pattern in fetal life are associated with long-term decreases in cortisol (Wang et al. 2011).

In rodents, it has been demonstrated that adult offspring from mothers who were exposed to nicotine during gestation and/or lactation become obese and have other metabolic disorders such as cardiovascular disorders, permanent $\beta$-cell loss, and insulin resistance (Bruin et al. 2007, Somm et al. 2009). Therefore, it seems that nicotine has the potential to act as an obesogenic factor in the offspring. In fact, our laboratory confirmed this hypothesis using an experimental model of maternal exposure exclusively to nicotine only during lactation. Nicotine is transferred by breast milk and promotes, in pups, higher body fat mass with metabolic alterations featured by hyperleptinemia, primary thyroid hypofunction, and higher adrenal catecholamine content and corticosterone levels (Oliveira et al. 2009, 2010). In adult life, it programs the progeny for overweight and higher adiposity associated with leptin and insulin resistance as well as secondary hypothyroidism with alterations in the leptin signaling pathway of hypothalamus-pituitary-thyroid axis (Oliveira et al. 2009, de Oliveira et al. 2010, Santos-Silva et al. 2010).

As there are other components besides nicotine in cigarettes, the association of nicotine with other tobacco smoke components may have different or combined effects in children/progeny compared with those effects previously observed in several studies when the mothers were exposed to nicotine alone. Thus, to test this hypothesis, we designed an experimental model where dams were exposed to tobacco smoke during lactation separated of their pups, i.e. we studied the effects of tobacco smoke components transferred only by milk. This model was justified because a considerable proportion of smoking mothers relapse to drug use during lactation but avoid smoking in the same environment as the child. We detected higher cotinine levels in maternal milk, similar to those found in the model of maternal nicotine exposure. Also, there were important alterations in breast milk composition such as higher triglyceride and lactose levels (Santos-Silva et al. 2011). Again, these findings were similar to those observed in the model of maternal nicotine exposure (Oliveira et al. 2010). Pups from dams who were exposed to smoke presented, at weaning, hypertriglyceridemia, hyperinsulinemia, hypocorticosteronemia, lower adrenal catecholamine content, and no change in body weight or adiposity (Santos-Silva et al. 2011). Surprisingly, when adults, these offspring were programmed only for adrenal dysfunction, characterized by decreased total adrenal catecholamine content and tyrosine hydroxylase protein expression (Santos-Silva et al. 2012). These findings were different from those obtained from the maternal nicotine model (Oliveira et al. 2009, de Oliveira et al. 2010), suggesting that the combination of nicotine and other cigarette components programs for different outcomes than the maternal nicotine model.

Actually, children from smoking mothers are exposed to cigarette components not only through breast milk but also through the household environment. The WHO (2009) showed that $40 \%$ of children are submitted to cigarette components by environmental tobacco smoke, when at least one of their parents is a smoker. Children exposed to environmental tobacco present higher serum leptin, C-reactive protein, fibrinogen, and interleukin-6 levels (Nagel et al. 2009), which suggest more susceptibility to cardiovascular disease. As exclusive maternal smoke exposure (SE) fails to reproduce most of the programming effects of maternal nicotine exposure, and in order to try to reproduce what really can happen to children from smoker parents who are exposed to cigarette components both by breast milk and by direct inhalation, we design this study where both dams and pups were exposed to tobacco smoke during lactation to better understand the immediate and late repercussions of early environmental smoking on rat offspring's development and endocrine function.

\section{Materials and methods}

Wistar rats were kept in a room with controlled temperature $\left(25 \pm 1^{\circ} \mathrm{C}\right)$ and with artificial dark-light cycles $(0700 \mathrm{~h}$ light: $1900 \mathrm{~h}$ darkness cycle). Nulliparous 90-day-old female rats were caged with male rats at a proportion of 2:1. After mating, each pregnant rat was placed in an

Published by Bioscientifica Ltd 
individual cage with water and food ad libitum until delivery. The use of animals in our experimental design was approved by the Animal Care and Use of the Biology Institute of the State University of Rio de Janeiro (CEUA/016/2009). The handling of experimental animals was according to the principles adopted in Brazil according the Brazilian Law no. 11.794/2008 (Marques et al. 2009).

\section{Model of neonatal exposure to cigarette smoke during lactation}

On the third day after delivery, lactating rats with their litters were randomly assigned to one of the following groups until weaning period (21 days of lactation):

- SE group ( $n=8$ dams) - dams and offspring were placed into a smoking machine (TE-10, Teague Enterprises, Davis, CA, USA) four times per day ( $1 \mathrm{~h}$ each exposure). This machine generated tobacco smoke from one research cigarette type $2 \mathrm{R} 1 \mathrm{~F}$ at a time (nicotine $=1.74 \mathrm{mg} / \mathrm{cigt}$; total particulate matter $=28.6 \mathrm{mg} / \mathrm{cigt} ; \operatorname{tar}=23.4 \mathrm{mg} / \mathrm{cigt}$; carbon monoxide $=22.0 \mathrm{mg} / \mathrm{cigt}$; Reference Cigarette Program, University of Kentucky, Lexington, KY, USA). A smoke mixture containing $89 \%$ sidestream smoke (smoke released from the burning end of a cigarette) and $11 \%$ mainstream smoke (smoke from the puff stream), as a surrogate for active smoking (AbreuVillaça et al. 2010, 2012), was generated by the smoking machine in a staggered manner at the rate of a single $35 \mathrm{ml}$ puff of 2-s duration each min. During exposure, the total suspended particulate was measured by weighing teflon-coated fiber filters (TX40H120-WW, Pallflex Products Co., Putnam, CT, USA) before and after a 5-min period, when air was collected from the chamber. There were 12 periods of collection, which generated levels of $38.4 \pm 3.9 \mathrm{mg} / \mathrm{m}^{3}$ (mean \pm s.E.M.).

- Control (C group, $n=8$ dams) - dams and offspring were exposed to filtered air in a similar chamber.

At birth, to maximize lactation performance, litters were adjusted for six male pups per SE or C dam. During lactation, pup's body weight was monitored daily and nose-rump length once a week. After weaning, pup's body weight and food intake were monitored every 4 days. We decapitated two pups per litter at weaning as well as at 180 days, with no prior anesthesia because anesthesia affects hormone and lipid metabolism. Blood samples, adipose tissue, and adrenal gland were collected and frozen at $-20^{\circ} \mathrm{C}$ for further analysis.

\section{Detection of cotinine (nicotine metabolite)}

At weaning, serum cotinine levels were determined using a cotinine assay kit from Orasure Technologies (Bethlehem, PA, USA) in accordance with the manufacture's recommendations. SE and C pups were killed (one pup/litter), the blood was collected, centrifuged at $2000 \boldsymbol{g}$ for $20 \mathrm{~min}$ at $4{ }^{\circ} \mathrm{C}$, and supernatant was stored at $-20^{\circ} \mathrm{C}$ until assaying.

\section{Body composition evaluation}

The central adiposity was determined at 21 and 180 days by weighing visceral fat mass (VFM) - mesenteric, epididymal, and retroperitoneal deposits. The carcass of $\mathrm{C}$ and SE offspring was weighed, autoclaved for $1 \mathrm{~h}$, and homogenized in distilled water (1:1). The homogenate was stored at $4{ }^{\circ} \mathrm{C}$ for analysis to determine fat content gravimetrically (Oliveira et al. 2009). Three grams of sample were hydrolyzed on a shaking water bath at $70{ }^{\circ} \mathrm{C}$ for $2 \mathrm{~h}$ with $30 \% \mathrm{KOH}$ and ethanol ( $3 \mathrm{ml}$ each). Samples were acidified with $2.5 \mathrm{ml} 6 \mathrm{M} \mathrm{H}_{2} \mathrm{SO}_{4}$. Total fatty acids and free cholesterol were removed by three successive washings with petroleum ether. After drying overnight in vacuum, all tubes were weighed and data were expressed as grams of fat by $100 \mathrm{~g}$ carcass. One gram of homogenate was used for determination of protein content by Lowry method (Lowry et al. 1951). Data were expressed as grams of protein by $100 \mathrm{~g}$ carcass.

\section{Morphological evaluation of the pup's adipose tissue}

Samples of subcutaneous and retroperitoneal adipose tissue from six SE and six C offspring (21 and 180 days) were fixed in buffered formaldehyde. After $24 \mathrm{~h}$ of fixation, samples were dehydrated, cleared, and paraffin embedded. Sections of $5 \mu \mathrm{m}$ were obtained (microtome Microtec-CUT 4050, SC, USA), placed into slides, and stained with hematoxylin/ eosin. A light microscope (model BX40 Olympus, Tokyo, Japan) coupled to a digital camera (Olympus DP7) was used to examine the morphology using a $20 \times$ objective. Morphometric analysis was performed in captured images from ten slides per animal. For each slide, the area of ten adipocytes was randomly selected and analyzed using the IMAGE-J/NHI software (Wayne Rasband National Institute of Health, Bethesda, MA, USA).

\section{Serum biochemical parameters}

Glucose was determined in blood samples from the tail vein of fasting rats using a glucometer (ACCU-CHEK

Published by Bioscientifica Ltd 
Advantage, Roche Diagnostics). Triglycerides, total cholesterol, and HDL cholesterol (HDL-C) fraction were analyzed using Biosystem commercial test kits with an automated A15 spectrophotometer (Biosystems S.A., Barcelona, Spain). LDL cholesterol (LDL-C) and VLDL cholesterol (VLDL-C) were calculated according to the Friedewald equation (Friedewald \& Levy 1972):

VLDL-C $=$ triglycerides $/ 5$.

LDL-C $=($ total cholesterol $-\mathrm{HDL}-\mathrm{C}-$ triglycerides $) / 5$.

\section{Serum hormone quantification by RIA and enzyme immunoassay}

Blood samples were centrifuged ( $1500 \mathrm{~g}$ for $20 \mathrm{~min}$ at $4{ }^{\circ} \mathrm{C}$ ) to obtain sera, which were kept at $-20^{\circ} \mathrm{C}$ until the assay. All measurements were performed in one assay. The assay sensitivity, intra-assay variation, and kit provider are shown in Table 1.

\section{Adrenal catecholamine content measurement}

For this, left adrenal gland was homogenized in $500 \mu 1 \quad 10 \%$ acetic acid and centrifuged at $1120 \boldsymbol{g}$ for $5 \mathrm{~min}$. To assay, $50 \mu \mathrm{l}$ of the supernatant/epinephrine standards were mixed with $250 \mu \mathrm{l}$ buffer phosphate $0.5 \mathrm{M}$, $\mathrm{pH} 7.0$, and $25 \mu \mathrm{l}$ potassium ferricyanide $0.5 \%$, followed by incubation ( $20 \mathrm{~min}$; ice bath). Reaction was stopped with $500 \mu \mathrm{l}$ ascorbic acid/NaOH $10 \mathrm{M}$ (1:19 proportion). Parameters used in the fluorometer (Victor2, PerkinElmer, Waltham, MA, USA) were $420 \mathrm{~nm}$ excitation and $510 \mathrm{~nm}$ emission. Results were obtained by plotting the values into a linear regression of the standard epinephrine curve. Data were expressed in $\mu \mathrm{M}$ catecholamine/mg gland (Trevenzoli et al. 2007).

\section{Statistical analysis}

GraphPad Prism 5 was used for statistical analyses and graphics (GraphPad Software, Inc., La Jolla, CA, USA). Results were reported as mean \pm s.E.M. Changes in body weight and food intake were analyzed by two-way ANOVA and Newman-Keuls multiple comparison tests. The other experimental data were analyzed by unpaired Student's $t$-test with significance level set at $P<0.05$. We studied two offspring from each mother per age. However, for the analyses, the litter was used as the experimental unit because we considered the average of values from animals of the same litter instead of using individual animal values.

\section{Results}

\section{Changes in pups at weaning}

At weaning, SE pups presented high serum cotinine levels $(145.3 \pm 5.1 \mathrm{ng} / \mathrm{ml})$ confirming tobacco exposure. Control pups had cotinine levels below the detection limit of the technique $(<8 \mathrm{ng} / \mathrm{ml})$. Cotinine levels found in $\mathrm{SE}$ animals are comparable with the levels detected in women heavy smokers (Eskenazi \& Bergmann 1995).

Figure 1 shows that SE pups presented significant lower body weight from the fourth day of life to weaning $(-7 \%$ at 21 days; $P<0.05)$, lower nose-rump length $(-5 \%$ at 21 days; $P<0.05$ ), and lower retroperitoneal fat depot $(-59 \% ; P<0.05)$ compared with $C$ pups at weaning without change in mesenteric and epididymal fat depots or in total body fat and total body protein. Figure 2 presents morphometric analysis of adipose tissue of SE and $\mathrm{C}$ pups at 21 days. SE pups showed lower retroperitoneal adipocyte area $(-60 \% ; P<0.05)$ and higher subcutaneous adipocyte area $(+95 \% ; P<0.05)$.

Table 2 shows the hormone profile of SE pups at weaning. These animals presented lower serum insulin

Table 1 Assay sensitivity, intra-assay variation, and kit provider of RIA and enzyme immunoassay (EIA) used in the present study

Insulin
Leptin
Corticosterone
Total triiodothyronine $\left(\mathrm{TT}_{3}\right)$
Free thyroxine $\left(\mathrm{FT}_{4}\right)$
Serum TSH
ACTH
Adiponectin

\begin{tabular}{|c|c|}
\hline $\begin{array}{l}\text { Assay } \\
\text { sensitivity }\end{array}$ & $\begin{array}{l}\text { Intra-assay } \\
\text { variation (\%) }\end{array}$ \\
\hline $1 \mathrm{ng} / \mathrm{ml}$ & 8.9 \\
\hline $0.5 \mathrm{ng} / \mathrm{ml}$ & 2.9 \\
\hline $50 \mathrm{ng} / \mathrm{ml}$ & 7 \\
\hline $25 \mathrm{ng} / \mathrm{dl}$ & 3.5 \\
\hline $0.3 \mathrm{ng} / \mathrm{dl}$ & 6.5 \\
\hline $0.18 \mathrm{ng} / \mathrm{ml}$ & 2.3 \\
\hline $0.1 \mathrm{ng} / \mathrm{ml}$ & 10 \\
\hline $0.155 \mathrm{ng} / \mathrm{ml}$ & 2 \\
\hline
\end{tabular}

\section{Provider}

RIA kit (ImmuChem TM 125 I, coated tube, ICN Biomedicals, Inc., NY, USA)

RIA kit (Linco Research, Inc., St Louis, MO, USA)

RIA kit (ICN Biomedicals, Inc., Aurora, OH, USA)

RIA kit (ICN Pharmaceuticals, Inc., Los Angeles, CA, USA)

RIA kit (ICN Pharmaceuticals, Inc.)

RIA kit expressed in terms of the reference preparation-3 (RP-3) supplied by NIH (USA)

EIA kit (Phoenix Pharmaceuticals, Inc, Burlingame, CA, USA)

EIA kit (Millipore, Billerica, MA, USA) http://joe.endocrinology-journals.org DOI: 10.1530/JOE-13-0003
C 2013 Society for Endocrinology Printed in Great Britain
Published by Bioscientifica Ltd. 
A

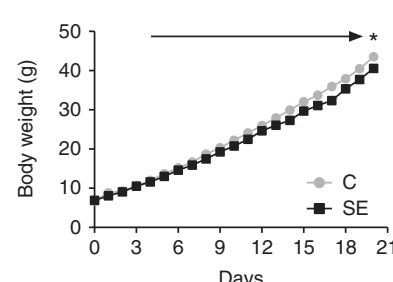

B
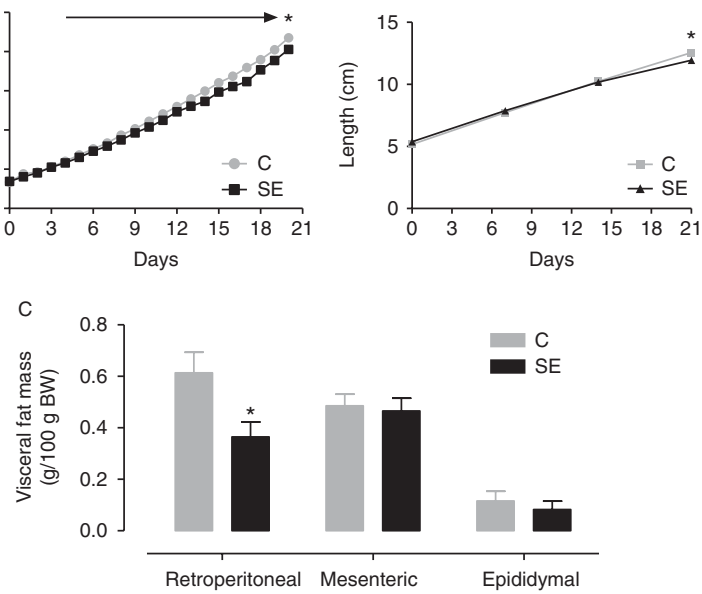

D
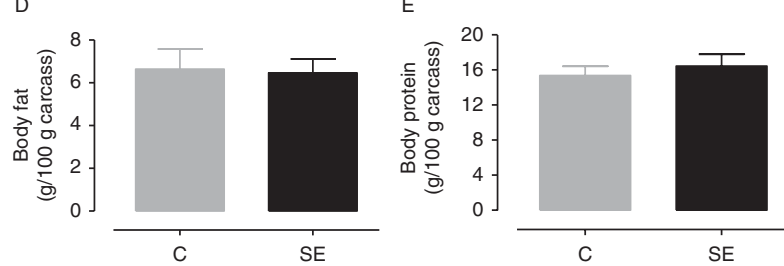

Figure 1

Body weight (A), nose-rump length (B), white adipose tissue depots (C), total body fat (D), and total body protein (E) of weaned pups who were exposed to tobacco smoke (black) or not (gray) during lactation. Values represent mean and S.E.M. of eight pups per group. ${ }^{\star} P<0.05$.

$(-29 \% ; P<0.05)$, higher free thyroxine $\left(\mathrm{FT}_{4}\right)(+59 \%$; $P<0.05)$, higher corticosterone $(+60 \% ; P<0.05)$, and higher adrenal catecholamine content $(+58 \% ; P<0.05)$ without changing the other analyzed parameters.

\section{Changes in pups in adult life}

As depicted in Fig. 3, adult SE offspring presented no change in body weight when compared with $\mathrm{C}$ offspring, although they had higher cumulative food intake $(+10 \%$; $P<0.05)$, which was confirmed by the significant difference of area under the curve (AUC) of temporal evolution of the food ingestion $(+13 \% ; P<0.05)$.

Regarding body composition, SE offspring presented higher fat mass in all visceral depots (retroperitoneal: $+55 \%$; mesenteric: $+67 \%$; and epididymal: $+55 \%$; $P<0.05)$, higher total body fat $(+50 \% ; P<0.05)$ without change in total body protein. Figure 4 presents the morphometric analysis of adipose tissue at 180 days. The SE group only showed lower subcutaneous adipocyte area $(-24 \% ; P<0.05)$ than $C$ group with no change in retroperitoneal adipocyte area.

The hormone profile at 180 days is depicted in Table 3. The SE group presented normoinsulinemia, hyperglycemia $(+11 \% ; P<0.05)$, hyperleptinemia $(+85 \%$; $P<0.05)$, and hyperadiponectinemia $(+1.40$-fold increase; $P<0.05$ ), while both corticosteronemia and adrenal catecholamine contents were lower (41 and 57\% respectively; $P<0.05)$. Concerning the thyroid status, the SE group showed higher serum TSH $(+36 \% ; P<0.05)$, total triiodothyronine $\left(\mathrm{TT}_{3}\right)(+71 \% ; P<0.05)$, and $\mathrm{FT}_{4}$ $(+57 \%$; $P<0.05)$ levels compared with the $\mathrm{C}$ group. The lipid profile at 180 days is presented in Table 4 . SE offspring showed higher triglycerides $(+65 \%$; $P<0.05)$, HDL-C $(+91 \% ; P<0.05)$, and VLDL-C $(+66 \% ; P<0.05)$ than controls without changing the total cholesterol or LDL-C.

\section{Discussion}

It is well known that normal conditions in early periods of life are essential for healthy development of humans, and several environmental factors, such as smoking exposure, at this stage can lead to complications in growth and future
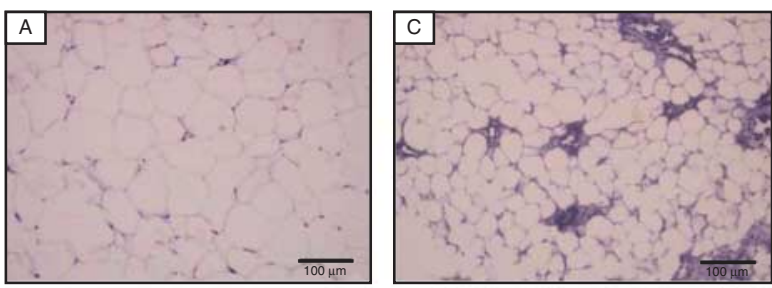

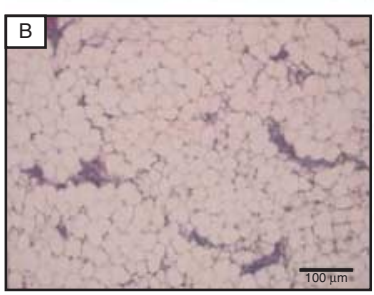

Retroperitoneal adipocytes E

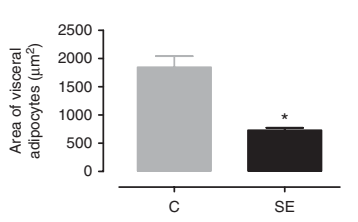

Figure 2

Photomicrography of adipose tissue at 21 days. (A) Retroperitoneal adipose tissue from control rats, (B) retroperitoneal adipose tissue from SE rats, (C) subcutaneous adipose tissue from control rats, (D) subcutaneous adipose tissue from SE rats, (E) morphometric analysis of retroperitoneal adipose tissue from pups who were exposed to tobacco smoke (black) or not (gray) during lactation, and (F) morphometric analysis of subcutaneous adipose tissue from pups who were exposed to tobacco smoke (black) or not (gray) during lactation. Values represent mean and S.E.M. of six pups per group. $* P<0.05$.

Published by Bioscientifica Ltd. 
Table 2 Blood glucose and hormones of 21-day-old offspring who were exposed to tobacco smoke or not during lactation. Values represent mean \pm s.E.M. of eight rat pups per group

Glycemia $(\mathrm{mg} / \mathrm{dl})$
Serum insulin $(\mu \mathrm{lU} / \mathrm{ml})$
Serum leptin $(\mathrm{ng} / \mathrm{ml})$
Adrenal catecholamine content $(\mu \mathrm{M} / \mathrm{mg})$
Serum corticosterone $(\mathrm{ng} / \mathrm{ml})$
Serum $\mathrm{TT}_{3}(\mathrm{ng} / \mathrm{dl})$
Serum $\mathrm{FT}_{4}(\mathrm{ng} / \mathrm{dl})$
Serum TSH $(\mathrm{ng} / \mathrm{ml})$

$\mathrm{TT}_{3}$, total triiodothyronine; $\mathrm{FT}_{4}$, free thyroxine.

${ }^{a}$ Significant differences between groups. functional characteristics (Ibrahin 2010, Gil et al. 2011). The higher subcutaneous adipocyte area can be explained by its characteristic of triglyceride storage. As lactating dams who were exposed to smoke have higher milk triglyceride transfer (Santos-Silva et al. 2011), SE pups who were fed with a milk rich in triglycerides are likely to have a higher uptake of this lipid by subcutaneous adipocyte tissues. Distinctively, the lower retroperitoneal adipocyte area could be associated with the fact that this tissue is more sensitive to a lipolytic activity of catecholamines (Ibrahin 2010). In fact, we detected higher adrenal total catecholamine content in SE pups, and if it means a higher
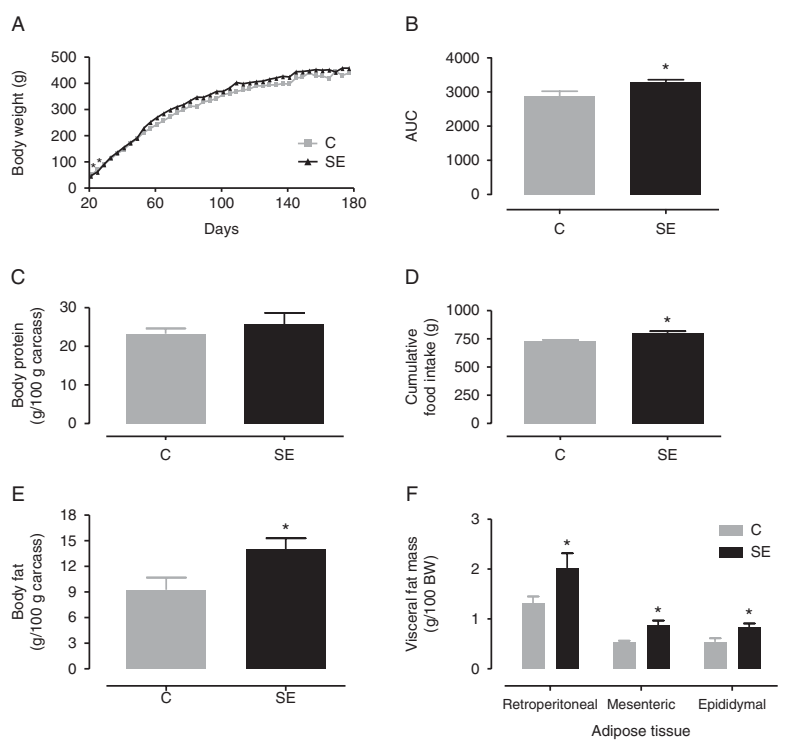

Figure 3

(A) Body weight, (B) AUC of food intake evalution, (C) Total body protein, (D) Cumulative Food intake, (E) Total body fat and (F) White adiposetissue depots of adult rats who were exposed to tobacco smoke (black) or not (gray) during lactation. Values represent mean and S.E.M. of eight pups per group. ${ }^{*} P<0.05$. http://joe.endocrinology-journals.org DOI: 10.1530/JOE-13-0003
(C) 2013 Society for Endocrinology Printed in Great Britain 

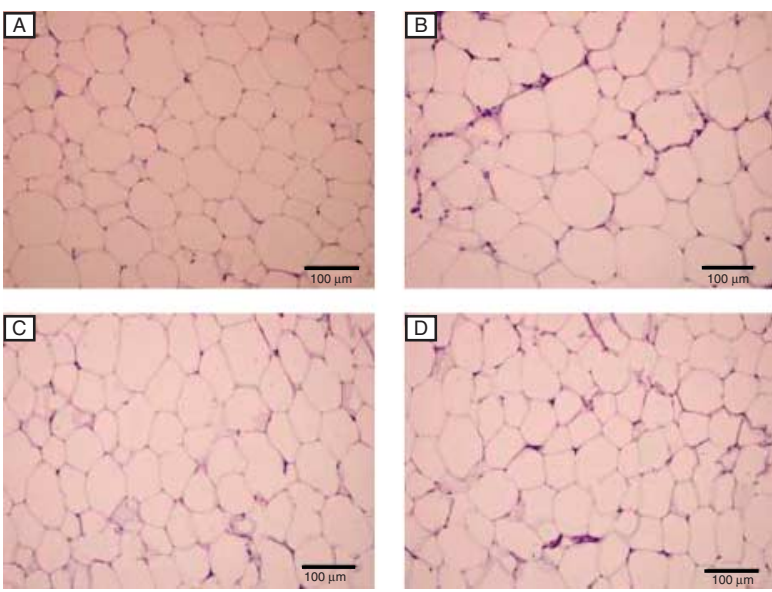

Retroperitoneal adipocytes

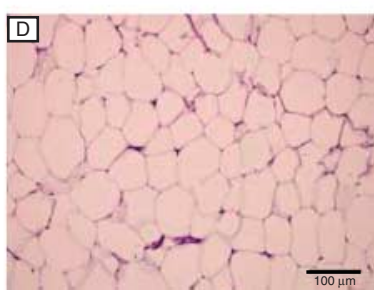

Subcutaneous adipocytes
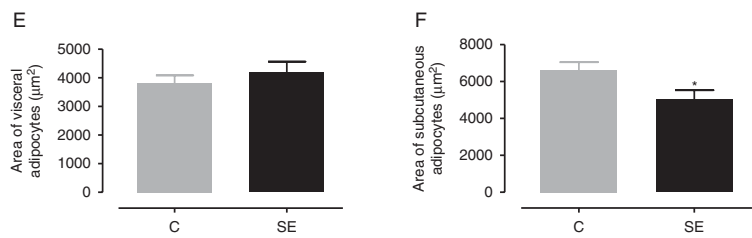

Figure 4

Photomicrography of adipose tissue at 180 days. (A) Retroperitoneal adipose tissue from control rats, (B) subcutaneous adipose tissue from control rats. (C) retroperitoneal adipose tissue from SE rats. (D) subcutaneous adipose tissue from SE rats, (E) morphometric analysis of retroperitoneal adipose tissue from pups who were exposed to tobacco smoke (black) or not (gray) during lactation, (F) morphometric analysis of subcutaneous adipose tissue from pups who were exposed to tobacco smoke (black) or not (gray) during lactation. Values represent mean and S.E.M. of six pups per group. ${ }^{*} P<0.05$.

hormone release, this effect could help to explain the reduced area of retroperitoneal adipocytes.

Regarding glucose homeostasis, we recently evidenced in rats that dams exposed to tobacco smoke displayed lower insulin levels and unchanged glycemia (Santos-Silva et al. 2011). Here, at weaning, SE pups also presented hypoinsulinemia with no change in fasting serum glucose, reinforcing the association between direct tobacco SE and decrease in insulinemia that was observed in other models with adult mice (Chen et al. 2007, 2008). This alteration can suggest higher insulin sensitivity or a lower insulin secretion. This last possibility was previously described in pancreatic islets, which were acutely treated with nicotine (Yoshikawa et al. 2005).

The hypercorticosteronemia and higher catecholamine content in adrenal medulla of SE pups suggest higher stimulation of the adrenal gland function that can make the animals more sensitive to environmental stressor conditions. As these changes were quite similar to those previously observed in suckling pups whose

mothers were exclusively exposed to nicotine during lactation (Oliveira et al. 2010), we suggest that the changes induced by neonatal tobacco SE are due to the presence of nicotine, which can be inhaled and present in the milk. The higher adrenal catecholamine content in SE offspring can be due to a higher biosynthesis or a lower secretion. As those animals supposedly had higher visceral adipocyte lypolitic activity, it is more likely that the catecholamine secretion is increased due to a higher production. Also, those animals that had hypercorticosteronemia and glucocorticoids have a well-known stimulatory effect on phenylethanolamine $\mathrm{N}$-methyltransferase in adrenal medullae, an enzyme that converts norepinephrine into epinephrine. Accordingly, the increase in catecholamine content may reflect a higher epinephrine production.

Despite the known anti-thyroid action described for some cigarette components such as thiocyanate and perchlorate (Dorea 2004, Steinmaus et al. 2007, Pearce $\&$ Braverman 2009), data from the literature addressing smoking and thyroid function are still controversial. Passive smoking induced lower $\mathrm{T}_{3}, \mathrm{~T}_{4}$, and TSH levels in adult women (Soldin et al. 2009) or higher $\mathrm{T}_{3}$ and $\mathrm{T}_{4}$ in adult men and women (Metsios et al. 2007); nicotine exposure did not change thyroid hormones and TSH levels in adult male rats (Colzani et al. 1998); and maternal smoking during pregnancy increased TSH levels in the blood cord (Shields et al. 2009). Here, the 21-dayold SE pups showed only higher serum $\mathrm{T}_{4}$, suggesting that tobacco smoke components act on peripheral TH metabolism, such as extra-thyroidal deiodination or liver non-deiodinative metabolism (glucuronidation or desamination). This higher $\mathrm{T}_{4}$ without significant changes in TSH reflects an inappropriate pituitary

Table 3 Blood glucose and hormones of 180-day-old offspring who were exposed to tobacco smoke or not during lactation. Values represent mean \pm S.E.M. of eight rat pups per group

Glycemia (mg/dl)

Serum insulin $(\mu \mathrm{lU} / \mathrm{ml})$

Serum adiponectin $(\mathrm{ng} / \mathrm{dl})$

Serum leptin ( $\mathrm{ng} / \mathrm{ml})$

Adrenal catecholamine content $(\mu \mathrm{M} / \mathrm{mg})$

Serum corticosterone $(\mathrm{ng} / \mathrm{ml})$

Serum ACTH $(\mathrm{ng} / \mathrm{ml})$

Serum $\mathrm{TT}_{3}(\mathrm{ng} / \mathrm{dl})$

Serum $\mathrm{FT}_{4}$ (ng/dl)

Serum TSH (ng/ml)

\begin{tabular}{c} 
Control group \\
\hline $69.9 \pm 2.6$ \\
$25.9 \pm 2.4$ \\
$8.44 \pm 2.0$ \\
$9.7 \pm 1.8$ \\
$1.4 \pm 0.3$ \\
$347.9 \pm 33.4$ \\
$3.42 \pm 0.31$ \\
$51.6 \pm 5.0$ \\
$1.27 \pm 0.21$ \\
$0.19 \pm 0.01$ \\
\hline
\end{tabular}

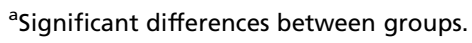

Smoke group

$77.7 \pm 1.8^{\mathrm{a}}$

$24.3 \pm 2.8$

$20.24 \pm 4.3^{a}$

$17.9 \pm 2.2^{\mathrm{a}}$

$0.8 \pm 0.1^{a}$

$203.8 \pm 47.9^{a}$

$4.49 \pm 0.65$

$88.4 \pm 9.1^{\text {a }}$

$2.00+0.15^{\mathrm{a}}$

$0.26 \pm 0.03^{a}$

Published by Bioscientifica Ltd 
Table 4 Lipid profile of 180-day-old offspring who were exposed to tobacco smoke or not during lactation. Values represent mean \pm s.E.M. of eight rat pups per group

\begin{tabular}{lcccc}
\hline & & Control group & & Smoke group \\
\cline { 1 - 1 } Total cholesterol $(\mathrm{mg} / \mathrm{dl})$ & & $62.3 \pm 3.9$ & & $86.5 \pm 14.0$ \\
Triglycerides $(\mathrm{mg} / \mathrm{dl})$ & & $48.9 \pm 3.5$ & & $80.7 \pm 11.7^{\mathrm{a}}$ \\
HDL-C (mg/dl) & & $21.7 \pm 1.1$ & & $41.5 \pm 2.6^{\mathrm{a}}$ \\
LDL-C (mg/dl) & $30.9 \pm 3.7$ & & $43.3 \pm 9.9$ \\
VLDL-C (mg/dl) & $9.7 \pm 0.7$ & & $16.2 \pm 2.4^{\mathrm{a}}$ \\
\hline
\end{tabular}

HDL-C, high-density lipoprotein cholesterol; LDL-C, low-density lipoprotein cholesterol; VLDL-C, very-low-density lipoprotein cholesterol.

${ }^{\text {aS }}$ Significant differences between groups.

response to $\mathrm{T}_{4}$, which can occur in situations of chronic diseases or malnutrition, typically found in low $\mathrm{T}_{3}$ syndrome. Despite the fact that serum $\mathrm{T}_{3}$ is not significantly lower, it was $10 \%$ lower than the values observed in the control group. This hypothesis should be tested for further understanding of the relationship between tobacco smoke and thyroid dysfunction. We evidenced that neonate pups whose mothers were exposed to nicotine during lactation presented a primary hypothyroidism (Oliveira et al. 2009). Therefore, in this study, it is likely that the other cigarette compounds changed the effects of nicotine on thyroid function.

\section{Adulthood alterations}

After weaning, the SE group presented a catch-up growth, because body weights of $\mathrm{SE}$ and control groups were similar in adult life. Furthermore, SE offspring showed a higher total and VFM that could not be explained only by the small increment of cumulative food intake. The development of late-onset obesity is frequently associated with maternal smoking during gestation in humans (von Kries et al. 2002, Wideroe et al. 2003, Goldani et al. 2007, Koshy et al. 2010, Durmus et al. 2011) and with maternal nicotine exposure during gestation/lactation in experimental studies (Holloway et al. 2005, Somm et al. 2008, 2009, Oliveira et al. 2009). Here, the same outcome was found in rats exposed to tobacco smoke exclusively in postnatal life both by transfer through the milk and direct inhalation (sidestream smoking).

Concerning adipocyte morphology, despite higher adiposity, adult SE offspring showed no change in visceral adipocyte area. However, these offspring were programmed for a lower subcutaneous adipocyte area. Some studies showed that subcutaneous abdominal adipocyte area is positively associated with unfavorable metabolic indexes (Imbeault et al. 1999). Larger adipocytes release lower amounts of adiponectin (Skurk et al. 2007, Bambace et al. 2011). Thus, the lower subcutaneous adipocyte area may counterbalance the higher VFM, which could be responsible for hyperglycemia and hypertriglyceridemia, increasing adiponectin production. As previously proposed by Miyazaki et al. (2010), our findings suggest that reducing adipocyte size may be a potential strategy to decouple obesity from obesity-related diseases, as smoke-exposed adult animals were programmed for obesity but had higher adiponectin and HDL-C serum levels.

In adult life, higher body adiposity, hyperleptinemia and higher food intake are suggestive of central leptin resistance (de Oliveira et al. 2010), as physiolocally hyperleptinemia causes hypophagia. Among the cigarette compounds, nicotine may have triggered leptin resistance because we previously showed that maternal nicotine exposure during lactation programmed for lower OB-R, lower JAK2, lower p-STAT3, and higher SOCS3, which is a well-known intracellular inhibitor of the leptin signaling pathway in the hypothalamus of the adult progeny, featuring a central leptin resistance (de Oliveira et al. 2010).

Different from that observed at weaning, adult SE offspring presented higher fasting glucose without changes in insulinemia, suggesting a glucose intolerance programming, also observed in adult rats exposed to nicotine on perinatal life (Somm et al. 2009, de Oliveira et al. 2010). It is possible that this inappropriate insulin secretion is the beginning of a pancreatic $\beta$-cell failure.

Again, in contrast to that observed at weaning, adult SE offspring had hypocorticosteronemia and lower adrenal catecholamine content. A similar profile was observed in an experimental model of nicotine withdrawal, in which CRH mRNA expression was unchanged, suggesting subsensitivity of the HPA axis immediately after smoking cessation (Semba et al. 2004). However, the adrenal profile of SE offspring is the opposite of the adult offspring programmed by nicotine during lactation, which presented hypercorticosteronemia and higher adrenal catecholamine content (Pinheiro et al. 2011). Therefore, regarding adrenal function, the isolated nicotine effects differ from those elicited by the combined tobacco smoke components.

Regarding thyroid function, adult SE offspring showed higher $\mathrm{T}_{3}, \mathrm{~T}_{4}$, and TSH serum levels, showing that this higher thyroid hormone production is consequent to a thyrotrope hyperfunction, which is contrary to the secondary hypothyroidism found in adult rats whose mothers were exposed to nicotine during lactation (Oliveira et al. 2009). The hyperphagia found in adult SE

Published by Bioscientifica Ltd. 
offspring suggests a functional hyperthyroidism, as $T_{3}$ increases food intake through its action on energy expenditure and appetite circuits of the nervous system (Amin et al. 2011). The association between higher adiposity and higher thyroid hormones (that leads to an increase in energy expenditure) in the SE group may seem to be contradictory. However, some studies have described an increase in $\mathrm{T}_{3}$ and higher adiposity as an adaptive mechanism that occurs in obesity (Reinehr et al. 2006, 2008, Alevizaki et al. 2009, de Pergola et al. 2010). The hyperthyroid status of the SE group can be partially explained by hyperleptinemia as leptin has a well-known stimulatory action on the thyroid axis (Casanueva \& Dieguez 1999, Nowak et al. 2002, Ortiga-Carvalho et al. 2002, de Oliveira et al. 2007). There is also an association between hyperthyroidism and hyperadiponectinemia (Yaturu et al. 2004, Seifi et al. 2012), which could help to explain the present findings in adult SE rats.

Even without ever having smoked, adults or adolescents exposed to environmental tobacco smoke have a higher risk of developing cardiometabolic diseases (Weitzman et al. 2005, Venn \& Britton 2007, Xie et al. 2010). We evidenced that neonatal tobacco smoke programs for higher triglycerides, VLDL-C, and HDL-C in adult life. Initially, higher HDL-C seems to be contradictory as tobacco SE is associated with lower serum HDL-C in children (Nagel et al. 2009, Hirata et al. 2010). However, increased HDL-C was found in adult female rats who were exposed to tobacco smoke during gestation without change in total antioxidant capacity, suggesting that higher HDL-C is non-functional (Ng et al. 2009). Concerning higher triglyceride and VLDL-C levels in adult SE pups, an increase in these serum lipids has been described in both active and passive smokers (Whig et al. 1992). Thus, the a changes in adiposity, hyperglycemia, and hypertriglyceridemia observed in SE adult progeny suggest that neonatal tobacco smoke acts as one imprinting/priming factor for future development of the metabolic syndrome. As adult offspring whose mothers were exposed to nicotine during lactation did not develop changes in lipid profile (Oliveira et al. 2010), the changes in lipid profile observed here were due to other cigarette components.

The comparison among distinct models of tobacco smoke and nicotine exposure leads to the following relevant inferences: i) the differences observed between the effects of tobacco SE exclusively through milk (indirect tobacco exposure) and tobacco SE both by breast milk and by direct inhalation are related to the serum cotinine levels of the offspring (indirect exposure model: 17.9 $\pm 4.2 \mathrm{ng} / \mathrm{ml}$ vs milk transfer and inhalation exposure model: $145.3 \pm 5.1 \mathrm{ng} / \mathrm{ml})$, confirming the greater exposure to tobacco smoke in pups of the second experimental model; ii) in the tobacco SE model, we observed some similar effects compared with isolated nicotine (e.g. higher adrenal function at weaning and higher adiposity at adulthood); however, we also observed opposite effects between the two models (e.g. body weight at weaning and thyroid and adrenal functions at adulthood). Despite similar and/or different findings among the three experimental models (smoke component exposure only through milk, smoke chemical exposure via milk, and direct inhalation and isolated nicotine exposure), we cannot forget that the exposure to tobacco presented in this study is the model that best represents what happens to children exposed to environmental smoking. Also, the comparison between the different models is important to identify the factors and mechanisms that cause the changes associated with tobacco exposure. These factors could be better explored in future experiment performing, for instance, some dynamic tests such as GTT and CRH stimulation.

We conclude that neonatal tobacco exposure only during the lactation period (derived by either inhalation or milk transfer of constituents from cigarette smoke) was capable of promoting important metabolic changes since childhood. These metabolic disorders worsened during development, as adult animals were programmed for obesity, hyperleptinemia, hyperglycemia, dyslipidemia, hypocorticosteronemia, and thyroid dysfunction. Therefore, wide distribution of information about the importance of a tobacco-free environment is necessary to ensure adequate development in children.

\section{Declaration of interest}

The authors declare that there is no conflict of interest that could be perceived as prejudicing the impartiality of the research reported.

\section{Funding}

This work was supported by the 'National Council for Scientific and Technological Development' (Conselho Nacional de Desenvolvimento Científico e Tecnológico-CNPq), the 'Coordination for the Enhancement of Higher Education Personnel' (Coordenação de Aperfeiçoamento de Pessoal de Nivel Superior - CAPES), and the 'Carlos Chagas Filho Research Foundation of the State of Rio de Janeiro' (Fundação Carlos Chagas Filho de Amparo à Pesquisa do Estado do Rio de Janeiro - FAPERJ). A P S-S and C R P were recipients of the CNPq fellowship.

\section{Acknowledgements}

All authors are grateful to Mr Jose Firmino Nogueira-Neto (Lab-Lip), Mr Ulisses Siqueira Risso, and Miss Monica Moura for technical assistance.

Published by Bioscientifica Ltd 


\section{References}

Abreu-Villaça Y, Filgueiras CC, Guthierrez M, Medeiros AH, Mattos MA, Pereira Mdos S, Manhães AC \& Kubrusly RC 2010 Exposure to tobacco smoke containing either high or low levels of nicotine during adolescence: differential effects on choline uptake in the cerebral cortex and hippocampus. Nicotine \& Tobacco Research 12 776-788. (doi:10.1093/ntr/ntq075)

Abreu-Villaça Y, Graça CCC, Ribeiro-Carvalho A, Naiff V, Manhães AC \& Filgueiras CC 2012 Combined exposure to tobacco smoke and ethanol in adolescent mice elicits memory and learning deficits both during exposure and withdrawal. Nicotine \& Tobacco Research. In press. (doi: 10.1093/ntr/nts250)

Alevizaki M, Saltiki K, Voidonikola P, Mantzou E, Papamichael C \& Stamatelopoulos K 2009 Free thyroxine is an independent predictor of subcutaneous fat in euthyroid individuals. European Journal of Endocrinology 161 459-465. (doi:10.1530/EJE-09-0441)

Amin A, Dhillo WS \& Murphy KG 2013 The central effects of thyroid hormones on appetite. Journal of Thyroid Research. In press.

Bambace C, Telesca M, Zoico E, Sepe A, Olioso D, Rossi A, Corzato F, Di Francesco V, Mazzucco A, Santini F et al. 2011 Adiponectin gene expression and adipocyte diameter: a comparison between epicardial and subcutaneous adipose tissue in men. Cardiovascular Pathology 20 153-156. (doi:10.1016/j.carpath.2010.07.005)

Braun JM, Daniels JL, Poole C, Olshan AF, Hornung R, Bernert JT, Khoury J, Needham LL, Barr DB \& Lanphear BP 2010 Prenatal environmental tobacco smoke exposure and early childhood body mass index. Paediatric and Perinatal Epidemiology 24 524-534. (doi:10.1111/j.13653016.2010.01146.x)

Bruin JE, Kellenberger LD, Gerstein HC, Mmorrison K \& Holloway AC 2007 Fetal and neonatal nicotine exposure and postnatal glucose: identifying critical windows of exposure. Journal of Endocrinology 194 171-178. (doi:10.1677/JOE-07-0050)

Casanueva FF \& Dieguez C 1999 Neuroendocrine regulation and actions of leptin. Frontiers in Neuroendocrinology 20 317-363. (doi:10.1006/frne. 1999.0187)

Chen H, Hansen MJ, Jones JE, Vlahos R, Anderson GP \& Morris MJ 2007 Detrimental metabolic effects of combining long term cigarette smoke exposure and high-fat diet in mice. American Journal of Physiology. Endocrinology and Metabolism 293 1564-1571. (doi:10.1152/ajpendo. 00442.2007)

Chen H, Hansen MJ, Jones JE, Vlahos R, Anderson GP \& Morris MJ 2008 Long-term cigarette smoke exposure increases uncoupling protein expression but reduces energy intake. Brain Research 1228 81-88. (doi:10.1016/j.brainres.2008.06.067)

Chiolero A, Faeh D, Paccaud F \& Cornuz J 2008 Consequences of smoking for body weight, body distribution and insulin resistance. American Journal Clinical of Nutrition 87 801-809.

Colzani R, Fang SL, Alex S \& Braverman LE 1998 The effect of nicotine on thyroid function in rats. Metabolism 47 154-157. (doi:10.1016/S00260495(98)90212-8)

Dorea JG 2004 Maternal thiocyanate and thyroid status during breastfeeding. Journal of the American College of Nutrition 23 97-101.

Durmus B, Kruithof CJ, Gilmar MH, Willensen SP, Hofman A, Raat H, Eilers PHC, Steegers EAP \& Jaddoe VWV 2011 Parental smoking during pregnancy: early growth, and risk of obesity in preschool children: the Generation R Study. American Journal of Clinical Nutrition 94 164-171. (doi:10.3945/ajcn.110.009225)

Einarson A \& Riordan S 2009 Smoking in pregnancy and lactation: a review of risks and cessation strategies. European Journal of Clinical Pharmacology 65 325-330. (doi:10.1007/s00228-008-0609-0)

Eskenazi B \& Bergmann JJ 1995 Passive and active maternal smoking during pregnancy, as measured by serum cotinine, and postnatal smoke exposure. I. Effects on physical growth at age 5 years. American Journal of Epidemiology 142 10-18. (doi:10.1093/aje/142.Supplement_9.S10)
Friedewald WT \& Levy RI 1972 Estimation of the concentration of low density lipoprotein cholesterol in plasma, without use of the preparative ultracentrifuge. Clinical Chemistry 18 499-502.

Gil A, Olza J, Gil-Campos M, Gomes-Llorente C \& Aquilera CM 2011 Is adipose tissue metabolically different at different sites? International Journal of Pediatric Obesity 6 13-20. (doi:10.3109/17477166.2011. 604326)

Goldani MZ, Haeffner LSB, Agranonik M, Barbieri MA, Bettiol H \& Silva AAM 2007 Do early life factors influence body mass index in adolescents? Brazilian Journal of Medical and Biological Research $\mathbf{4 0 1}$ 1231-1236. (doi:10.1590/S0100-879X2006005000131)

Hirata K, Yamano Y, Suzuki H, Miyagawa S \& Nakadate T 2010 Passive smoking is associated with lower serum HDL-C levels in school children. Pediatrics International 52 252-256. (doi:10.1111/j.1442200X.2009.02957.x)

Holloway AC, Lim GE, Petrik JJ, Foster WJ, Morrison KM \& Gerstein HC 2005 Fetal and neonatal exposure to nicotine in Wistar rats results in increased $\beta$ cell apoptosis at birth and postnatal endocrine and metabolic changes associated with type 2 diabetes. Diabetologia 48 2661-2666. (doi:10.1007/s00125-005-0022-5)

Ibrahin MM 2010 Subcutaneous and visceral adipose tissue: structural and functional differences. Obesity Reviews 11 11-18. (doi:10.1111/j.1467789X.2009.00623.x)

Imbeault P, Lemieux S, Prud'homme D, Tremblay A, Nadeau A, Després JP \& Mauriège P 1999 Relationship of visceral adipose tissue to metabolic risk factors for coronary heart disease: is there a contribution of subcutaneous fat cell hypertrophy? Metabolism 48 355-362. (doi:10.1016/S0026-0495(99)90085-9)

Klesges RC, Ward KD, Ray JW, Cutter G, Jacobs DR Jr \& Wagenknecht LE 1998 The prospective relationships between smoking and weight in a young, biracial cohort: the Coronary Artery Risk Development in Young Adults Study. Journal of Consulting and Clinical Psychology 66 987-993. (doi:10.1037/0022-006X.66.6.987)

Koshy G, Delpisheh A \& Bradin BJ 2010 Dose response association of pregnancy cigarette smoke exposure, childhood stature, overweight and obesity. European Journal of Public Health 21 286-291. (doi:10.1093/ eurpub/ckq173)

von Kries R, Toschke AM, Koletzko B \& Slikker W 2002 Maternal smoking during pregnancy and childhood obesity. American Journal of Epidemiology 156 954-961. (doi:10.1093/aje/kwf128)

Li MD \& Kane JK 2003 Effects of nicotine on the expression of leptin and forebrain leptin receptor in the rat. Brain Research 991 222-231. (doi:10.1016/j.brainres.2003.08.024)

Lisboa PC, Oliveira E \& Moura EG 2012 Obesity and endocrine dysfunction programmed by maternal smoking in pregnancy and lactation. Frontiers in Physiology 3 1-9. (doi:10.3389/fphys.2012.00437)

Lowry OH, Roseberough NJ, Farr AL \& Randal RJ 1951 Protein measurement with the Folin phenol reagent. Journal of Biological Chemistry 193 265-275.

Marques RG, Morales MM \& Petroianu A 2009 Brazilian law for scientific use of animals. Acta Cirurgica Brasileira 24 69-74. (doi:10.1590/S0102$86502009000100015)$

Metsios GS, Flouris AD, Jamurtas AZ, Carrillo AE, Kouretas D, Germenis AE, Gourgoulianis K, Kiropoulos T, Tzatzarakis MN, Tsatsakis AM et al. 2007 A brief exposure to moderate passive smoke increases metabolism and thyroid hormone secretion. Journal of Clinical Endocrinology and Metabolism 92 208-211. (doi:10.1210/jc.2006-0762)

Miyazaki S, Izawa T, Ogasawara JE, Sakurai T, Nomura S, Kizaki T, Ohno H \& Komabayashi T 2010 Effect of exercise training on adipocyte-sizedependent expression of leptin and adiponectin. Life Sciences $\mathbf{8 6}$ 691-698. (doi:10.1016/j.lfs.2010.03.004)

de Moura EG, Lisboa PC \& Passos MC 2008 Neonatal programming of neuroimmunomodulation - role of adipocytokines and neuropeptides. Neuroimmunomodulation 15 176-188. (doi:10.1159/000153422)

Nagel G, Arnold FJ, Wilhelm M, Link B, Zoellner I \& Koenig W 2009 Environmental tobacco smoke and cardiometabolic risk in young http://joe.endocrinology-journals.org DOI: $10.1530 /$ JOE-13-0003
() 2013 Society for Endocrinology Printed in Great Britain 
children: results from a survey in south-west Germany. European Heart Journal 30 1885-1893. (doi:10.1093/eurheartj/ehp180)

Ng SP, Conklin DJ, Bhatnagar A, Bolanowski DD, Lyon J \& Zelikoff JT 2009 Prenatal exposure to cigarette smoke induces diet- and sex-dependent dyslipidemia and weight gain in adult murine offspring. Environmental Health Perspectives 117 1042-1048. (doi:10.1289/ehp.0800193)

Nowak KW, Kaczmarek P, Mackwiak P, Ziolkowiak A, Albertin G, Ginda WJ, Trejter M, Nussdorfer GG \& Malendowicz LK 2002 Rat thyroid gland expresses the long form of leptin receptors, and leptin stimulates the function of the gland in euthyroid non-fasted animals. International Journal of Molecular Medicine 9 31-34.

de Oliveira E, Fagundes ATS, Bonomo IT, Curty FH, Passos MCF, Moura EG \& Lisboa PC 2007 Acute and chronic leptin effect upon in vivo and in vitro rat thyroid iodide uptake. Life Sciences 81 1241-1246. (doi:10.1016/j.lfs.2007.08.030)

de Oliveira E, Moura EG, Santos-Silva AP, Pinheiro CR, Lima NS, Nogueira-NetoJF, Nunes-Freitas AL, Abreu-Villaça Y, Passos MCF \& Lisboa PC 2010 Neonatal nicotine exposure causes insulin and leptin resistance and inhibits hypothalamic leptin signaling in adult rats offspring. Journal of Endocrinology 206 55-63. (doi:10.1677/JOE-10-0104)

Oliveira E, Moura E, Santos-Silva A, Fagundes A, Rios A, Abreu-Villaca Y, Nogueira-Neto JF, Passos MCF \& Lisboa PC 2009 Short and long-term effects of maternal nicotine exposure during lactation on body adiposity, lipid profile and thyroid function of rat offspring. Journal of Endocrinology 202 397-405. (doi:10.1677/JOE-09-0020)

Oliveira E, Pinheiro CR, Santos-Silva AP, Trevenzoli IH, Abreu-Villaça Y, Nogueira Neto JF, Reis AM, Passos MC, Moura EG \& Lisboa PC 2010 Nicotine exposure effects mother's and pup's nutriotional, biochemical and hormonal profile during lactation in rats. Journal of Endocrinology 205 159-170. (doi:10.1677/JOE-09-0430)

Ortiga-Carvalho TM, Oliveira KL, Soares BA \& Pazos-Moura CC 2002 The role of leptin in the regulation of TSH secretion in the fed state: in vivo and in vitro studies. Journal of Endocrinology 174 121-125. (doi:10.1677/joe.0.1740121)

Pearce EN \& Braverman LE 2009 Environmental pollutants and the thyroid. Best Practice \& Research. Clinical Endocrinology \& Metabolism 23 801-813. (doi:10.1016/j.beem.2009.06.003)

de Pergola G, Ciampolillo A, Alò D, Sciaraffia M \& Guida P 2010 Free triiodothyronine is associated with smoking habit, independently of obesity, body fat distribution, insulin, and metabolic parameters. Journal of Endocrinological Investigation 815-818. (doi:10.3275/7168)

Pinheiro CR, Oliveira E, Trevenzoli IH, Manhães AC, Santos-Silva AP, Younes-Rappozo V, Claudio-Neto S, Santana AC, Nascimento-Saba CCA, Moura EG et al. 2011 Developmental plasticity in adrenal function and leptin production primed by nicotine exposure during lactation: gender differences in rats. Hormone and Metabolic Research $\mathbf{4 3}$ 1-9. (doi:10.1055/s-0030-1267203)

Reinehr T, Souza G \& Andler W 2006 Hyperthyrotropinemia in obese children is reversible after weight loss is not related to lipids. Journal of Clinical Endocrinology and Metabolism 91 3088-3091. (doi:10.1210/jc. 2006-0095)

Reinehr T, Isa A, Souza G, Dieffenbach R \& Andler W 2008 Thyroid hormones and their relation to weight status. Hormone Research $\mathbf{7 0}$ 51-57. (doi:10.1159/000129678)

Santos-Silva AP, Moura EG, Pinheiro CR, Rios AS, Abreu-Villaça Y, Passos MC, Oliveira E \& Lisboa PC 2010 Neonatal nicotine exposure alters leptin signaling in the hypothalamus-pituitary-thyroid axis in the postnatal period and adulthood in rats. Life Sciences 87 187-195. (doi:10.1016/j.lfs.2010.06.012)

Santos-Silva AP, Oliveira E, Pinheiro CR, Nunes-Freitas AL, Abreu-Villaça Y, Santana AC, Nascimento-Saba CC, Nogueira-Neto JF, Reis AM, Moura EG et al. 2011 Effects of maternal tobacco smoke exposure during lactation on nutritional and hormonal profiles in mothers and offspring. Journal of Endocrinology 209 1-11. (doi:10.1530/JOE-10-0410) Santos-Silva AP, Lisboa PC, Pinheiro CR, Maia LA, Peixoto-Silva N, Abreu-Villaça Y, Moura EG \& Oliveira E 2012 Maternal tobacco smoke exposure during lactation inhibits catecholamine production by adrenal medullae in adult rat offspring. Hormone and Metabolic Research 44 550-554. (doi:10.1055/s-0032-1312597)

Seifi S, Tabandeh MR, Nazifi S, Saeb M, Shirian S \& Sarkoohi P 2012 Regulation of adiponectin gene expression in adipose tissue by thyroid hormones. Journal of Physiology and Biochemistry 68 193-203. (doi:10.1007/s13105-011-0131-1)

Semba J, Wakuta M, Maeda J \& Suhara T 2004 Nicotine withdrawal induces subsensibility of hypothamalus-pituitary-adrenal axis to stress in rats: implications for precipitation of depression during smoking cessation. Psychoneuroendocrinology 29 215-226. (doi:10.1016/S0306-4530 (03)00024-6)

Shields B, Hill A, Bilous M, Knight B, Hattersley AT, Bilous RW \& Vaidya B 2009 Cigarette smoking during pregnancy is associated with alterations in maternal and fetal thyroid function. Journal of Clinical Endocrinology and Metabolism 94 570-574. (doi:10.1210/jc.2008-0380)

Shimada T, Hiramatsu N, Hayakawa K, Takahashi S, Kasai A, Tagawa Y, Mukai M, Yao J, Fujii-Kuriyama Y \& Kitamura M 2009 Dual supression of adipogenesis by cigarette smoke through activation of the aryl hydrocarbon receptor and induction of endoplasmic reticulum stress. American Journal of Physiology. Endocrinology and Metabolism 296 721-730. (doi:10.1152/ajpendo.90829.2008)

Skurk T, Alberti-Huber C, Herder C \& Hauner H 2007 Relationship between adipocyte size and adipokine expression and secretion. Journal of Clinical Endocrinology and Metabolism 92 1023-1033. (doi:10.1210/jc. 2006-1055)

Soldin OP, Goughenour BE, Gilbert SZ, Landy HJ \& Soldin SJ 2009 Thyroid hormone levels associated with active and passive cigarette smoking. Thyroid 19 817-823. (doi:10.1089/thy.2009.0023)

Somm E, Schwitzgebel VM, Vauthay DM, Camm EJ, Chen CY, Giacobino JP, Sizonenko SV, Aubert ML \& Hüppi PS 2008 Prenatal nicotine exposure alters early pancreatic islet and adipose tissue development with consequences and the control of body weight and glucose metabolism later in life. Endocrinology 149 6289-6299. (doi:10.1210/en. 2008-0361)

Somm E, Schwitzgebel VM, Vauthay DM, Aubert ML \& Huüppi PS 2009 Prenatal nicotine exposure and the programming of metabolic and cardiovascular disorders. Molecular and Cellular Endocrinology 304 69-77. (doi:10.1016/j.mce.2009.02.026)

Steinmaus C, Miller MD \& Howd R 2007 Impact of smoking and thiocyanate on perchlorate and thyroid hormone associations in the 2001-2002 national health and nutrition examination survey. Environmental Health Perspectives 115 1333-1338. (doi:10.1289/ehp.10300)

Stice E \& Martinez EE 2005 Cigarette smoking prospectively predicts retarded physical growth among female adolescents. Journal of Adolescent Health 37 363-370. (doi:10.1016/j.jadohealth.2004.10.017)

Suter M, Abramovici A \& Aagaard-Tillery K 2010 Genetic and epigenetic influence associated with intrauterine growth restriction due to in utero tobacco exposure. Pediatric Endocrinology Reviews 8 94-102.

Suter M, Ma J, Harris A, Patterson L, Brown KA, Shope C, Showalter L, Abramovici A \& Aagaard-Tillery KM 2011 Maternal tobacco use modestly alters correlated epigenome-wide placental DNA methylation and gene expression. Epigenetics 6 1284-1294. (doi:10.4161/epi.6.11.17819)

Trevenzoli IH, Valle MMR, Machado FB, Garcia RMG, Passos MCF, Lisboa PC \& Moura EG 2007 Neonatal hyperleptinemia programmes adrenal medulary function in adult rats: effects on cardiovascular parameter. Journal of Physiology 580 629-637. (doi:10.1113/jphysiol. 2006.126151)

Venn A \& Britton J 2007 Exposure to secondhand smoke and biomarkers of cardiovascular disease risk in never-smoking adults. Circulation 115 990-995. (doi:10.1161/CIRCULATIONAHA.106.648469)

Wang T, Chem M, Liu L, Cheng H, Yan YE, Feng YH \& Wang H 2011 Nicotine induces CpG methylation of Pax binding motif in StAR promoter reduces the gene expression and cortisol production. Toxicology and Applied Pharmacology 257 328-337. (doi:10.1016/j.taap. 2011.09.016) 
Weitzman M, Cook S, Auinger P, Florin TA, Daniels S, Nguyen M \& Winickoff JP 2005 Tobacco smoke exposure is associated with the metabolic syndrome in adolescents. Circulation 112 862-869. (doi:10.1161/CIRCULATIONAHA.104.520650)

Whig J, Singh CB, Soni GL \& Bansal AK 1992 Serum lipids and lipoprotein profiles of cigarette smokers, passive smokers. Indian Journal of Medical Research 96 282-287.

Wideroe M, Vik T, Jacobsen G \& Bakketeig LS 2003 Does maternal smoking during pregnancy cause childhood overweight? Paediatric and Perinatal Epidemiology 17 171-179. (doi:10.1046/j.1365-3016.2003.00481.x)

World Health Organization 2009 WHO Report on the global tobacco epidemic - implementing smoke-free environments. pp 7-28. Bloomberg Pilanthropies.
World Health Organization 2010 WHO World No Tobacco Day - gender and tobacco with an emphasis on marketing to women. Bloomberg Pilanthropies.

Xie B, Palmer PH, Pang Z, Sun P, Duan H \& Jonhson CA 2010 Environmental tobacco use and indicators of metabolic syndrome in Chinese adults. Nicotine \& Tobacco Research 12 198-206. (doi:10.1093/ ntr/ntp194)

Yaturu S, Prado S \& Grimes SR 2004 Changes in adipocyte hormone leptin, resistin, and adiponectin in thyroid dysfunction. Journal of Cellular Biochemistry 93 491-496. (doi:10.1002/jcb.20188)

Yoshikawa H, Hellstrom-Lindahl E \& Grill V 2005 Evidence for functional nicotine receptors on pancreatic $\beta$ cells. Metabolism: Clinical and Experimental 54 247-254. (doi:10.1016/j.metabol.2004.08.020)

Received in final form 6 April 2013

Accepted 18 April 2013

Accepted Preprint published online 18 April 2013
C 2013 Society for Endocrinology Printed in Great Britain
Published by Bioscientifica Ltd. 